\title{
Modification of the AlSi7Mg0.3 Alloy Using Antimony
}

Jaromir Cais ${ }^{1}$, Jaroslava Svobodova ${ }^{1}$, Dana Stancekova ${ }^{2}$

${ }^{1}$ Faculty of Mechanical Engineering, J. E. Purkyně University in Ústí nad Labem, Pasteurova 7, 40001 Ústí nad Labem. Czech Republic. E-mail: jaromir.cais@ujep.cz, jaroslava.svobodova@ujep.cz

${ }^{2}$ Faculty of Mechanical Engineering, University of Zilina, Univerzitna 1, 01026 Zilina. Slovakia. E-mail: dana.stancekova@fstroj.uniza.sk

The paper describes the research focused on the influence of the antimony as the modificator in the one of the most common aluminium foundry alloys - alloy AlSi7Mg0.3. The aim of described experiment was to examine the antimony addition influence on the AISi7Mg0.3 alloy microstructure changes. The description of the changes was performed based on the analysis realized using confocal laser microscope and electron microscope complemented by energy dispersive spectrometry in microstructure induced by the addition of antimony. The changes in the alloy microstructure, which were evoked by the addition of antimony, caused the mechanical properties changes (especially ductility). This is the main purpose of the Al-Si alloy modification process. Mechanical properties of the alloy were analysed using static tensile test and the main parameter of the observed changes was the increase in ductility.

Keywords: Al-Si Alloy, Microstructure Changes, Modification, Ductility, Antimony

\section{References}

[1] MAKHLOUF, M., GUTHZY, H. (2001). The aluminum-silicon eutectic reaction: mechanisms and crystallography. In: Journal of Light Metals, Vol. 1, No. 1, pp. $199-218$.

[2] DAHLE, A., NOGITA, K., MCDONALD, S., DINNIS, C., L. (2005). Eutectic modification and microstructure development in Al-Si Alloys. In: Materials Science and Engineering A, pp. 243 - 248.

[3] NOGITA, K., DAHLE, A. (2001). Eutectic Growth Mode in Strontium, Antimony and Phosphorus Modified Hypoeutectic Al-Si Foundry Alloys. In: Materials Transactions, Vol. 42, No. 3, pp. 393 - 396.

[4] XIUFANG, B., WEIMIN, W., JINGYU, Q. (2001). Liquid structure of Al $\pm 12.5 \%$ Si alloy modified by antimony. In: Materials Characterization, pp. 21-25.

[5] KNUUTINEN, A., NOGITA, K., MCDONALD, S., DAHLE, A. (2001). Modification of Al-Si alloys with Ba, Ca, Y and Yb. In: Journal of Light Metals, pp. 229 - 240.

[6] NÁPRSTKOVÁ, N., CAIS, J., INGALDI, M. (2016). Modification of AlSi9CuMnNi Alloy by Antimony and Heat Treatment and Their Influence on Tool Wear after Turning. In: Manufacturing Technology, Vol. 16, No. 1, pp. 209 - 214.

[7] NÁPRSTKOVÁ, N., CAIS, J., SVOBOdOVÁ, J. (2013). The Effect of Modification by Strontium of the AlSi7Mg0.3 Alloy on the Surface Roughness. In: Manufacturing Technology, Vol. 13, No. 3, pp. $380-384$.

[8] SVOBODOVÁ, J., CAIS, J., MICHNA, Š., BRŮHA M. (2013). Research of Corrosion Properties of Al-Si alloys antimony alloyed. In: Manufacturing Technology, Vol. 13, No. 3, pp. $404-409$.

[9] MICHNA, Š., HONZÁTKO, R., CAIS, J. (2013). Analysis of Causes Al2MgO4 - Type Spinel Inclusion Formation in Low-Pressure Casting. In: Manufacturing Technology, Vol. 13, No.3, p. 361 - 368. 